інноваційні технології та інноваційні методики навчання у підготовці фахівців: методологія, теорія, досвід, проблеми: зб. наук. праць. - Вінниця : Вінницький державний педагогічний університет імені Михайла Коцюбинського, 2010.Вип. 25. - С. 265-272.

\title{
ЛІНГВОДИДАКТИЧНИЙ ПОТЕНЦІАЛМІЖКУЛЬТУРНОГО СПІЛКУВАННЯ ЯК КАТЕГОРІЯ МЕТОДИКИ НАВЧАННЯ ІНОЗЕМНИХ МОВ
}

Махінов В. М. Лінгводидактичний потенціал міжкультурного спілкування як категорія методики навчання іноземних мов.

У статті розглядаються теоретичні засади міжкультурного спілкування як категорії методики навчання іноземних мов та їх лінгводидактичний потенціал, теоретично обгрунтовано нову міжкультурну лінгводидактичну парадигму, в основу якої покладено концепт формування мовної особистості, що відкриває широкі можливості пошуку нових оптимальних шляхів удосконалення іншомовної освіти студентів.

Ключові слова:теоретичні засади міжкультурного спілкування, методика навчання іноземних мов, мовна особистість, мовленнєва діяльність, іншомовна освіта.

Махинов В. Н. Лингводидактический потенциал межкультурного общения как категория методики обучения иностранным языкам.

В статье рассматриваются теоретические основы межкультурного общения как категории методики обучения иностранным языкам и их лингводидактический потенциал,теоретически обоснована новая межкультурная лингводидактическая парадигма, в основу которой положен концепт формирования языковой личности, что открывает широкие возможности поиска новых оптимальных путей совершенствования иноязычной образования студентов.

Ключевые слова:теоретические основы межкультурного общения, методика обучения иностранных языков, языковая личность, речевая деятельность, иноязычное образование.

Machinov V. N. Lingvodidactical potential of intercultural communication as a category of methods of teaching foreign languages.

The article examines theoretical basics of intercultural communication as a category of methods of foreign language teaching and their linguistic and didactic potential, substantiated the new intercultural paradigm, which is based on the concept of forming the language personality, which opens up opportunities to search for new optimal ways of improving foreign language education students.

Key words:theoretical fundamentals of intercultural communication, methodology of teaching of foreign languages, linguistic personality, speech activity, foreign language education.

Головним завданням лінгводидактики як загальної теорії навчання іноземної мови є розроблення методології навчання мови, аналіз застосовуваних дослідницьких підходів, прийомів, принципів і концепцій. Наукова цінність лінгводидактичної теорії, як найвищої форми організації наукового знання, вимірюється обсягом емпіричних фактів, які складають предмет іiі вивчення. Вона охоплює сфери систематизації, 
класифікації та інтерпретування (генеза, прогнозування подальшого розвитку), а також практичне застосування одержаних теоретичних висновківз метою поліпшити умови життя суспільства загалом і освітню галузь зокрема. Нині поширеною є думка: «Майбутнє за системою навчання, що вкладалося б у схему «студент - технологія викладач», за якої педагог перетворюється на технолога, а студент стає активним учасником процесу навчання» [5, с. 22]. Дефініція «міжкультурна комунікація» викликає безліч наукових суперечок і різних тлумачень у теоретичній думці і серед фахівців-практиків, оскільки поняття виформовувалося внаслідок компромісу багатьох наук. Нині досить поширеними і фактично синонімічними до нього є назви «крос-культурна комунікація», «міжетнічна комунікація», «міжкультурна інтеракція», «полікультурномовне спілкування», а також «крос-культурний / міжкультурний / лінгвокультурологічний підхід», «міжкультурна компетенція / компетентність» (теорія і методика навчання мови).

Культурологічний підхід до мовної освіти в наш час дедалі чіткіше оформлюється як окрема філософсько-філологічна парадигма тавідображений у працях зарубіжних (В. Біблер, С. Верещагін, В. Костомаров, Д. Лихачов, В. Маслова, С. Тер-Мінасова, Е. Холл) i вітчизняних науковців (Ф. Бацевич, П. Донець, С. Срмоленко, В. Жайворонок, Т. Космеда, Л. Мацько, Л. Скуратівський). Проблема технології навчання досліджується дидактами Н. Голуб, О. Горошкіною, В. Дороз, С. Караманом, Л. Кожуховською, Н. Остапенко, М. Пентилюк, К. Плиско, О. Потапенком, Т. Симоненко, Г. Шелеховою та іншими. Ідеї культуроцентристської концепції філологічної освіти набувають все більшої підтримки і в науковопедагогічному середовищі. На думку багатьох дослідників, вони слугують методологічним підгрунтям, що сприяє формуванню мовної полікультурної особистості сучасного студента як цілісного суб'єкта культури (Г. Слізарова, В. Кононенко, Г. Онкович, І. Плужник, В. Сафонова, Л. Саяхова, О. Семеног, В. Фурманова), сприяючи зокрема і формуванню культуромовної особистості [6].

У лінгводидактичних розвідках А. Буднік, Н. Голуб, О. Горошкіної, В. Дороз, Т. Левченко, О. Потапенка, Л. Прокопенко, О. Семеног, В. Тихоші, Г. Шелехової науково обгрунтовано потребу врахування національно-культурного компонента семантики мовних одиниць (передовсім лексики, фразеології і текстів художньої літератури) не лише як одиниць мови / мовлення, але й як концептів етнокультури.

Mema cmammi спрямована на пошук оптимальних шляхів аналізу проблематики міжкультурного спілкування на заняттях 3 іноземної мови. Основні завдання: окреслити місце і роль технологій у навчальній діяльності 3 мови; визначити специфіку технологічного підходу до методів організації іншомовної освіти. Відповідно до мети ми розглянемо феномени «міжкультурний», «спілкування», «комунікація», «компетенція» у колі суміжних понять; обгрунтуємо лінгводидактичного потенціалу «міжкультурно-комунікативна компетентність» як категорії методики навчання іноземної мови. Ми поділяємо думку тих науковців, які вважають: «методика навчання - це модель навчально-виховного процесу, яка інтегрує зміст навчання і навчальну технологію» [2, с. 7].

Сучасні науковці визначають технологію міжкультурного спілкування на заняттях $з$ іноземної мови як цілісну педагогічну систему, складниками якої є цілі, зміст, методи і засоби, послідовність дій суб'єктів і об'єктів навчально-виховного процесу. За рівнем застосування в педагогічному процесі технології поділяють на: загальнопедагогічні (застосовуються до всіх навчальних дисциплін); предметнометодичні (враховують специфіку вивчення окремого предмета); локальні, або 
внутрішньопредметні (враховують специфіку певної теми чи проблеми, стосуються окремого виду діяльності на занятті) - модульно-локальні мезотехнології і мікротехнології. Педагогічна технологія в межах курсу іноземної мови у ВНЗ реалізується в частковій технології навчання - прикладній методиці. Це система прийомів, об'єднаних певною логікою. Система методів - це основа навчальної технології. Система методів стає засобом технологізації навчання в тому разі, коли активна пізнавальна діяльність студентів зорієнтована на запланований освітній результат. Під технологією навчання можна розуміти комплекс форм, основних, допоміжних методів і засобів, пов'язаних з проектуванням, організацією та проведенням навчального процесу, що забезпечують досягнення запланованого результату.

Теорія міжкультурної комунікації як навчальна дисципліна спершу увійшла до навчальних планів факультетів іноземних мов або спеціалізації «Російська мова як іноземна», «Українська мова як іноземна», згодом закріпилася в Україні в межах професійної підготовки студентів філологічного профілю, які вивчають іноземні мови. Зміст означеної дисципліни охопив як загальнотеоретичні основи теорії і практики міжкультурної комунікації, так і суто прагматичні питання, пов'язані із особливостями культури мови, яка вивчається. Пріоритетність навчання діалогу культур зумовила значне зростанняінтересу до іноземних мов, що супроводжується зіставленням звичаїв, традицій, побуту різних народів, об'єктивно збільшила зацікавленість і власною етнокультурою у всіх їі різноманітних виявах і спричинила попит на дослідження національної культурної спадщини. У лінгводидактиці укорінилося розуміння міжкультурної комунікації як такої, за якої комунікативні партнери, належачи до різних мов і культур, усвідомлюють факт чужинності один одного. Науковці схильні вважати, що ця наукова парадигма перестає бути приналежністю лише сфери навчання іноземних мов, розповсюджуючись на широке проблемне поле гуманітарного, міждисциплінарного знання. Ф. Бацевич міжкультурну комунікацію характеризує тим, що іiі учасники у випадках прямого контакту використовують засоби мовного коду з культурно-специфічними смислами, а також стратегії і тактики спілкування, які відрізняються від тих, якими вони користуються у випадках інтеракції всередині культури [1, с.9], а також далі у словниковій статті: «Комунікація міжкультурна (у вузькому значенні слова) 1. Процес спілкування (вербального i невербального) людей (груп людей), які належать до різних національних лінгвокультурних спільнот, як правило, послуговуються різними ідіоетнічними мовами, мають різну комунікативну компетенцію, яка може стати причиною комунікативних невдач або культурного шоку в спілкуванні ... Одним із найважливіших чинників к. м. $є$ усвідомлення взаємної «культурної чужинності» іiї учасників. 2. Особливий тип культури, який характеризується взаємодією національних (етнічних) культур, етнокультурною компетенцією особистостей, толерантністю, прагненням до міжнаціональної згоди у всіх сферах спілкування» [1, с. 83].

Технологічний підхід у контексті іншомовної освіти у ВНЗ важливо розглядати 3 таких теоретичних позицій: технологічні дії в навчанні іноземної мови - це сукупність послідовних кроків від визначення цілей формування мовної особистості, попереднього проектування моделі навчально-виховного процесу з мови (навчальних ситуацій, уроків, позакласних заходів 3 іноземної мови) до реалізації на практиці поставлених завдань, 3 подальшою оцінкою та аналізом досягнутих результатів навчально-пізнавальної діяльності студентів; сучасні технології у сфері мовної освіти - навчальні системи, які відповідають найновішим досягненням дидактики, 
лінгвістики, теорії і практики навчання мови; вибір технології навчання залежить від мети, особливостей предметно-тематичного змісту навчальної діяльності студентів, рівня індивідуального розвитку, пізнавально-комунікативного досвіду, методичної майстерності викладача.

Поняття «комунікація» входить до категорій філософії, де воно «означає спілкування, за допомогою якого «я» виявляє себе в іншому (...), термін використовується також і в широкому розумінні, як спілкування» [9, с. 207]. «Спілкування - специфічний для суб'єктів спосіб взаємних відношень (...), спосіб буття людини у взаємозв'язках 3 іншими людьми ... У філософському сенсі спілкування не зводиться до навмисно виконуваних актів спілкування, до обміну інформацією i соціально-психологічних контактів» $[9$, с. 330]. У словнику лінгвістичних термінів означені поняття «комунікація» і «спілкування» розглянуто як абсолютні синоніми, що позначають «обмін думками, повідомленнями, ідеями специфічна форма взаємодії людей у процесі їх пізнавально-трудової діяльності» [10, с. 233]. У термінологічній енциклопедії О. Селіванової «комунікація» означає «процес інформаційного обміну між двома і більше сутностями за допомогою певної семіотичної системи (...), іноді ототожнюється зі спілкуванням, однак вони не є синонімічними. Спілкування є соціально зумовленим процесом обміну інформацією між людьми в різних сферах їхньої пізнавально-трудової та творчої діяльності, який реалізується переважно за допомогою вербальних засобів (...), хоча при розширенні сфери комунікативної лінгвістики, можливе їхнє дальше ототожнення за умови акцентування аспекту соціальної взаємодії в комунікації, а не лише інформаційного обміну» [8, с. 243-344]. До того ж дослідниця, посилаючись на засадничі положення соціології і психології, де, як правило, ці поняття не є тотожними, оскільки спілкування реально виявляється на 3-х рівнях (комунікативному, інтерактивному, перцептивному), доходить висновку, що комунікація $є$ ширшою за спілкування, а отже, міжкультурна комунікація - це «інформаційний обмін співрозмовників, належних до різних культур» [7, с. 303]. Поняття «комунікація» використовує і теорія інформації, зокрема в дослідженнях, які розробляють проблему «штучного інтелекту» (кібернетика), але при цьому воно фактично потлумачено і як синонім до слова «спілкування». Із наведених визначень, як бачимо, за спілкуванням здебільшого закріпилися характеристики міжособистісної взаємодії, а за комунікацією ще додаткове значення - інформаційний обмін у суспільстві. Саме на цій підставі Т. Грушевицька, В. Попов і О. Садохін тлумачать спілкування (мовленнєве уточнення наше) як «соціально зумовлений процес обміну думками, почуттями між людьми в різних галузях пізнавально-трудової і творчої діяльності, що реалізується переважно за допомогою вербальних засобів комунікації. На відміну від нього комунікація - соціально зумовлений процес передавання і сприймання інформації як у міжособистісному, так і в масовому спілкуванні на різних каналах з допомогою різних вербальних і невербальних комунікативних засобів» [3, с. 100]. Отже, у тлумаченні розглядуваних термінів так чи інакше дослідники оперують поняттям «інформація», розуміючи під останньою повідомлення про факти, події, процеси, звично оформлювані і передані мовними засобами.

Одна 3 ідей Концепції мовної освіти 12-річної школи (ми готуємо майбутнього вчителя для школи) полягає в тому, що використання сучасних технологій в організації навчального процесу сприятиме вдосконаленню національної системи шкільної мовної освіти. Звертається увага передусім на такі перспективні педагогічні системи, як: особистісно зорієнтовані технології, інформаційні освітні технології, технології 
модульного навчання, технології життєтворчості, вальдорфська педагогіка [4, с. 64].

Нині мета і завдання шкільного курсу іноземної мови розширилися. Система методів особистісно зорієнтованого навчання іноземної мови зазнає змін, за певних умов трансформується в технологію і достатньо обгрунтовано визначається як технологія навчання услід за загальнодидактичними тенденціями. Так, у дослідженнях методівінтерактивного навчання О. Пометун ототожнює їх 3 технологіями навчання: «Важливість технологічного підходу до реалізації інтерактивного навчання, складна структура кожного з таких методів дозволяють, на нашу думку, говорити про інтерактивні технології навчання» [6, с. 15]. Застосування технологічного підходу, спрямованого на модернізацію процесу мовної освіти, пов'язане 3 явними суперечностями між: 1) 3 одного боку, концептуальнометодологічним оновленням засад процесу мовної освіти і традиційною системою методів його реалізації, а 3 іншого, - сучасною соціальною вимогою у формуванні цілісної гармонійно розвиненої мовної особистості та недостатніми розвивальними можливостями традиційних методів навчання; 2) традиційною системою навчання, зорієнтованою на формування базових мовних, мовленнєвих знань, умінь, навичок, i об'єктивною потребою в застосуванні нового педагогічного досвіду, зокрема компетентнісного підходу до навчання, інтерактивних методів, інтегрованих технологій, зорієнтованих на посилення комунікативного аспекту у формуванні мовної особистості; 3) інтенсивним розвитком знань, інформаційних технологій і традиційною системою навчання мови, розвитку мовлення, що не надає змоги ефективно засвоювати знання, повною мірою входити до сучасного інформаційного простору; 4) повільним темпом навчальної діяльності студентів та і підвищенням інтересу до вивчення мови; 5) наявним рівнем навчальних досягнень студентів у сфері мовної освіти й об'єктивною потребою в постійному самовдосконаленні, самонавчанні, саморозвитку. Організація навчально-виховного процесу шляхом застосування системи методів на рівні сучасних технологій, спрямована на розв'язання наведених суперечностей, сприяє якісному вдосконаленню курсу іноземної мови у ВНЗ.

У межах запропонованого дослідження слід провеститермінологічне розмежування понять «міжкультурна комунікація (спілкування)» і«міжкультурна компетенція (компетентність)», оскільки цілком погоджуємося із О. Селівановою, що «одним із найголовніших завдань міжкультурної комунікації $\epsilon$ формування міжкультурної комунікативної компетенції на засадах культурного релятивізму й толерантності до чужої культури і мови, до їхніх культурних стандартів» [8, с. 349]. Якщо термін «компетенція міжкультурна»- це «знання чужих культурних стандартів» [8, с. 349], що забезпечує «формування вторинної мовної особистості, яка може себе реалізувати в межах діалогу культур» [1, с. 78] є цілком придатним дотично практики викладання іноземної мови, то визначення «міжкультурна компетентність» як «позитивне ставлення до наявності в суспільстві різних етнокультурних груп, (...) наявна як у індивіда, так і в державі на підставі політики добровільної адаптації соціальних і політичних інститутів суспільства до потреб різних культурних груп» [3, с. 277] безпосередньо стосується проблем мовної освіти. Це уможливлює дослідження процесів міжкультурного спілкування між представниками різних мовленнєвих субкультур усередині однієї й тієї ж національної культури титульного етносу.

Складники процесу мовної освіти мають забезпечити розвиток не тільки зовнішніх показників рівня мовних, мовленнєвих умінь та навичок студентів, а й внутрішніх пізнавальних потреб, особистісних утворень, ціннісних орієнтацій, когнітивного досвіду шляхом ефективного використання доступних методів, 
перспективних технологій навчання, спрямованих на його включення в активну навчально-пізнавальну діяльність задля досягнення заданого кінцевого результату. Відповідно до того, що час висуває прагнення до синтезованих способів навчання, потрібно звернути увагу на поняття функціональної системи методів навчання іноземної мови, пов'язане 3 проблемою технологізації методичних прийомів i співвідносне $з$ поняттям «технологічна система методів навчання», яке за своєю суттю є більш об'ємним і глибшим від суми окремих методів (з огляду на синергетичний показник, у складних системах число зв'язків між елементамизростає швидше, ніж число елементів). Технологічна система методів- це практично функціональна система методів, оскільки іiі можна розглядати і як у дії, і як теоретичну модель окремої технології, потенційно функціональну. На відміну від багаторівневої теоретичної системи методів [6, с. 13-14], функціональна складає основу певної технології навчання (візьмемо до уваги те, що в загальному тлумаченні технологія - це сукупність способів, тобто методів проведення виробничих (мовних та мовленнєвих) операцій. 3 цього випливає важливий методологічний висновок: аналіз феномену мови як утілення етнокультури освітнього простору неодмінно враховуватимевплив різноманітних європейських мов і культур, які характеризуються відносно стабільними особливостями саме завдяки генетичній спорідненості і спільності умов їх виникнення. Методи навчання мови здійснюють дидактичний уплив не поодинці, а сукупно; вони тісно взаємопов'язані, часто взаємопроникають, у результаті чого можуть складати цілісне процесуальне новоутворення - технологію, спрямовану на формування компетентної мовної особистості. У межах конкретної навчальної технології система методів набуває якісно нового змісту. Отже, функціональна система методів навчання іноземної мови - це практична лінгводидактична технологія, тобто технологія навчання мови, щогрунтується на сукупності методів, форм, засобів, які в конкретних навчальних умовах дозволяють педагогу, ураховуючи індивідуальні потреби майбутнього вчителя, забезпечити, з одного боку, суспільні потреби в національно свідомій, духовно багатій, комунікативній мовній особистості, а з іншого - актуальний рівень власне предметної підготовки студентів.

Нова міжкультурна лінгводидактична парадигма, в основу якої покладено концепт формування мовної особистості, відкриває широкі можливості пошуку нових оптимальних шляхів удосконалення іншомовної освіти студентів. Мовна особистість характеризується власним знанням мови й особливостями ії використання. Застосування технологічного підходу до методів навчання відкриває широкі можливості для модернізації процесуального складника мовної освіти, ефективного становлення й розвитку мовної особистості студентів. Мовна особистість студента становить єдність колективного й індивідуального, що виявляється у невідривному зв'язку між собою. Розглядаючи поняття «міжкультурна компетенція», як ресурсна якість, і «міжкультурна компетентність», як особистісне утворення, вважаємо необхідним увести до наукового обігу лінгводидактики вищої школи термін «міжкультурно-комунікативна компетентність» - інтегративна якість особистості, що характеризується сукупністю спеціальних міжкультурних знань i вмінь i системою ціннісних орієнтацій, необхідних для розв'язання фахових завдань в умовах міжкультурної мовної взаємодії у стилі співпраці і толерантності.

Реалії сучасної соціолінгвістичної ситуації в європейському освітньому просторі в перспективі потребують перегляду дидактичних положень лінгводидактики. Вивчення питань функціонування сучасних методів і технологій формування мовної особистості буде також продовжено в подальших дослідженнях автора. 


\section{Література}

1. Бацевич Ф. С. Словник термінів міжкультурної комунікації / Ф. С. Бацевич. К. : Довіра, 2007. - 205 с. 2. Биков В. Ю. Теоретико-методологічні засади моделювання навчального середовища педагогічних систем відкритої освіти / В. Ю. Биков // Наукові записки. Серія: Педагогічні науки. - Кіровоград : РВВ КДПУ ім. В. Винниченка. - 2008. - Випуск 77. - Частина 1. - С. 3-12. 3. Грушевицкая Т. Г. Основы межкультурной коммуникации : [учебник для вузов] / Т. Г. Грушевицкая, В. Д. Попов, А. П. Садовин; под ред. А. П. Садохина. - М. : Юнити-Дана, 2003. 352 с. 4. Концепція мовної освіти 12-річної школи // Дивослово. - 2002. - № 8. - С.5965. 5. Подранецька Н. Застосування проектних технологій на уроках української мови та літератури як один із напрямків розвитку мовної особистості / Н. Подранецька // Українська мова і література в школі. - 2006. - № 4. - С. 22-25. 6. Пометун О. Активні й інтерактивні методи навчання: до питання про диференціацію понять / О. Пометун // Шлях освіти. - 2004. - № 3. - С. 10-15. 7. Селіванова О. О. Сучасна лінгвістика: напрями та проблеми : [підручник] / О. О. Селіванова. - Полтава : Довкілля-К, 2008. - 712 с. 8. Селіванова О. О. Сучасна лінгвістика: термінологічна енциклопедія / О. О. Селіванова. - Полтава : Довкілля-К, 2006. - 716 с. 9. Философский словарь / под ред. И. Т. Фролова. - М. : Политиздат, 1987. - 590 c. 10. Языкознание. Большой энциклопедический словарь/гл. ред. В. Н. Ярцева. - М. : Большая Российская энциклопедия, 1998. - 685 с.

УДК 378.147(07)+371:811

Тетяна Мішеніна

\section{ЗМІСТ КУЛЬТУРОЛОГІЧНОГО СКЛАДНИКА У ФАХОВІЙ ПІДГОТОВЦІ МАЙБУТНІХ УЧИТЕЛІВ ФІЛОЛОГІЧНИХ СПЕЦІАЛЬНОСТЕЙ}

Мішеніна Т. М. Зміст культурологічного складника у фаховій підготовці майбутніх учителів філологічних спеціальностей.

У статті здійснено спробу розроблення змісту культурологічного складника у фаховій підготовці майбутніх філологів, об'єктивований у навчальних дисциплінах циклу гуманітарної й соціально-економічної підготовки. Розкрито сутність компаративного підходу до вивчення фахових дисциплін, який розуміється як розгляд мистецьких явищ (образотворчих, лінгвістичних і літературних) у межах культури / культур. Наведено приклади компаративних методик у змісті дисципліни «Лінгвістичний аналіз тексту».

Ключові слова: культурологічний складник, майбутні вчителі філологічних спеціальностей, дидактична компетентність, культурологічна компетенція, аксіологічна компетенція, компаративний підхід.

Мишенина T. M. Содержание культурологической составляющей в профессиональной подготовке будущих учителей филологических специальностей.

В статье сделана попытка разработки содержания культурологической составляющей в профессиональной подготовке будущих филологов, который реализуется в учебных дисциплинах цикла гуманитарной и социально-экономической подготовки. Раскрыта сущность компаративного подхода к изучению специальных дисциплин, которая понимается как рассмотрение явлений искусства (художественнографических, лингвистических и литературных) в рамках культуры / культур. Приведены примеры компаративных методик в содержании дисциплины 